\title{
Tasarım Sürecinin Bitkisel ve Yapısal Katman Dâhilinde Çözümlenmesi
}

\author{
Nilgün GÜNEROĞLU ${ }^{1 *}$, Makbulenur BEKAR ${ }^{1}$ \\ ${ }^{1}$ Karadeniz Teknik Üniversitesi, Orman Fakültesi, Peyzaj Mimarlığı Bölümü, 61080, TRABZON
}

\section{Öz}

Tasarım, bir senaryosu ve konsepti olan tek doğrusu olmayan bir süreci kapsamaktadır. Tasarım eğitimi alan tasarım öğrencileri stüdyo yöneticilerinin deneyimleri ve katkıları ile bu süreçlerini tamamlamaktadırlar. Süreç içerisinde konuya bakış açıları, araştırma yöntemleri, kazandıkları deneyimler ilerideki meslek hayatlarına etki etmekte ve tasarlayacakları projeleri biçimlendirmektedir. Bu nedenlerle tasarım öğrencilerinin eğitim-öğretim sürelerince farklı tasarım yaklaşımlarını ve tekniklerini deneyimlemeleri gerekmektedir. Katmanlaştırma, peyzaj tasarımlarında kullanılan her bir tasarım elemanının tek tek detaylandırılması ve bu tasarım elemanlarının birbirleriyle olan ilişkilerinin en iyi şekilde kurgulanmasını sağlayan bir yöntemdir. Peyzaj tasarımlarında yapısal ve bitkisel doku ayrı ayrı düşünülmemesi gereken, aynı amaca hizmet eden farklı katmanlardır. Peyzaj mimarlığı eğitiminde bitkisel katman çalışmaları tasarım sürecinin son aşamasında yer almaktadır. Proje için ayrılan süre yetmediği takdirde bitkisel katman gerektiği kadar detaylandırılamamakta ve yapısal katmanda alınan tasarım kararlarından farklı düşünülmektedir. Katmanlaştırma yöntemi bu gibi sorunlara çözüm olacağı gibi tasarım sürecini kısaltacak ve sonuç ürünün daha nitelikli olmasını sağlayacaktır. Bu nedenle bu çalışmada Karadeniz Teknik Üniversitesi Peyzaj Mimarlığı Bölümünde ikinci sınıf tasarım öğrencilerinin Çevre Tasarımı Proje-2 dersi kapsamında projelerini bitkisel ve yapısal olmak üzere iki katman dâhilinde çözmüşleri istenmiştir. Elde edilen sonuç ürünler incelenerek katmanlaştırma yönteminin tasarım eğitimindeki yeri, amacı ve tasarım öğrencilerine sağladığı katkılar tartışılmıştır. Sonuçta bitkisel katmanın da yapısal katman kadar detaylandırıldığı ve amacına uygun tasarlandığı belirlenmiştir.

Anahtar Kelimeler: Tasarım eğitimi, tasarım süreci, bitkisel katman, yapısal katman.

\section{Analysis of the Design Process in Planting and Structural Layer}

\section{Abstract}

Design is a process that has many aspects that appear as more than one rationale with definite scenario and concept. Design education of the students is completed in various colleges and universities by passing the knowledge and experience of their professional educators. This is such an important process that shapes the proficiency and talents of the students in their future designs as well as determines their position in working environment. Therefore, students have to experience different design techniques during their higher education stage. Layering is a special design technique in landscape architecture that accounts for linking each detailed design element of the project to each other by conceptualization of the reciprocal connections. Technically, structural and green textures serve for the same purpose and should not be interpreted separately as they together enhance the landscape design project. Unfortunately, layering of green cover or planting is taught in the last step of the design process in most of the landscape design schools. This may sometimes lead to ignoring or inadequate detailing of the green layer if there is not enough time for matching structural layer properties with planting layer. Layering technique can be the best solution for better and fast design process as well as producing more efficient final design product. In this study in order to improve their design abilities, students in second grade landscape architecture department of Karadeniz Tech. Unv. were asked to separate and solve their designs to structural and planting layers during the Landscape Project Design II course of the fall term. Finally, at the end of the course student works were received and evaluated in terms of the reflection the "layering concept" in their fall term design projects. It was observed that teaching and applying "layering" in landscape design education can greatly enhance the final product and give deeper insights to students when detailing the structural and planting layers in their layouts.

Keywords: Design education, design process, plant layer, structural layer. 


\section{Giriş}

Günümüzde teknolojik gelişmeler, zaman kaybını azaltmak, gerçeğe daha yakın ürünler ortaya koyarak olumsuzluklara anında müdehale edebilme gibi kolaylıkları sağlaması açısından tasarım çalışmalarına olumlu katkılar sunmaktadır. Özellikle tasarım yapılacak mekanların farklı boyut ve açıdaki görünümlerini simüle etme olanakları tasarımcıya tasarımı daha iyi sonuçlandırma imkanı sağlar. Teknolojik gelişmelerin her alana olduğu gibi tasarım çalışmalarına olan katkısı gözardı edilemez. Mimariye farklı bir bakış açısı sağlayan tasarımdaki gelişmeler özellikle peyzaj mimarlığında sürdürülebilirliği ön planda olan çözümlemelere olanak sunmaktadır. $\mathrm{Bu}$ çözümlemelerin ortaya çıkabilmesinde etkili olan tasarım ile ilgili farklı tanımlar ve yaklaşımlar bulunmaktadır. Genellikle problemlere çözüm üretme süreci olarak bilinen tasarım, kimilerine göre deneyerek çözüm bulma veya doğru karara ulaşma gibi tanımlamalarla açıklanmaktadır (Önal, 2011). Düşünme ile başlayan tasarım ürüne dönüşene kadar bir süreç izlemektedir. İşte bu süreç soyut düşüncelerin somut ifadelerle zihinde şekillenme aşamalarından oluşan düşünce üretme sürecidir (Paker Kahvecioğlı 2001). Başka bir ifade ile tasarım süreci "beyin sinir hücreleri arasındaki şebekelerin işleyişinin, kelebeklerin rastgele biryerlere uçup konmalarına benzer bir gizemde olduğu" benzetmesi ile açıklanmaktadır (Fischbach, 1992). Gestalt modelinde, tasarım süreci içerisindeki problem çözme aşamaları için "idrak” (insight) parametresi vardır. Bu görüş zihinde yeni organizasyonlar sağlayan bazı ilişki tiplerinin belirlenmesi ve en iyi çözüme ulaşmak için kullanılmaktadır (Paker Kahvecioğlı 2001). Tasarım sürecinde tasarımcı çalışacağı alan ile ilgili ulaşabileceği tüm verileri temin etmekte ve bunlara ek olarak alanı gözlemleyerek algılamaya çalışmaktadır (Çağlayan Kaptanoğlu 2008). Kısaca tek bir doğru cevabı olmayan bir problemi çözmektedir (Casakin 2011, Bonnardel, 2000). Tasarım sürecinde kullanılan birçok yöntem vardır. En genel kullanılan tipik yöntem ise esinlenmek/betimlemektir. Bu yöntemler kişisel birikimlere ve tasarımı ifade etme gücüne göre değişmektedir (Francis, 2001). Esinlenilen ürünler soyutlanır, fikir (Dorta, 2008) ve kavramsal konsept (Goldschmidt, 1997) dahilinde ortaya çıkar (Goldschmidt ve Sever, 2009).

Mimarlık, peyzaj mimarlı̆̆ı, şehir bölge planlama, iç mimarlık, endüstriyel tasarım gibi birçok disiplinde tasarım süreci içersinde belirlenecek olan konsept, konsepte bağlı ve hayal gücüyle oluşan kurguların nasıl öğretilebileceği önemli bir problemdir (Casakın, 2007). Bu noktada yaratıcılığın kişiye kazandırılması gereklidir. Eğitim süresince gerçekleştirilen projelerde tasarım öğrencilerinin bilişsel yetenekleri geliştirilmeli ve öğrenme olanakları arttırılmalıdır. Tasarım öğrencilerinin kendi fikirlerini sunması, bu fikirleri geliştirmeleri için ortamlar oluşturulmalıdır. Bu aşamada tasarım öğrencisi ve stüdyo yöneticisi arasındaki ilişkiye önem verilmelidir (Tezci, Gürol 2003). Tasarım öğrencilerinin elde ettikleri bilgileri uygulamaya aktarması, süreç içersinde oluşan gelişim ve değişimler için en önemli mekânlar tasarım stüdyolarıdır (Düzgün Bekdaş, Yıldız 2018; Demirbaş ve Demirkan, 2003). Tasarım stüdyoları, bilişsel bir stilinin işlendiği, bireysel farklılıklara yol açan ve bilgileri organize eden tercihlerin oluştuğu alanlardır (Roberts, 2005). Bu stüdyolarda, öğrenme stili ve tasarım öğrencilerinin akademik performansı arasında anlamlı korelasyonlar olduğunu gösteren çalışmalar yapılmıştır (Kvan and Yunyan 2005).

Tasarım eğitiminin ilk aşamasında tasarım öğrencilerin hayal ettikleri, kurguladıkları düşünceleri kâğıda aktarırken zorluk çekmektedir. Bunun nedeni sonuç ürünün somut olmasına rağmen soyut bir süreçle elde edildiğidir (Casakin, 2014; Düzenli ve Alpak, 2016). Eğitim-öğretim süreci boyunca gerçekleştirilen proje derslerinde tasarım öğrencilerinin hayal güçlerinin geliştirilmesi, fikirlerinin çizgilerle şekil bulması ve sonuç ürünlerin ortaya çıkmasında farklı yaklaşımlar kullanılmaktadır. Bu yaklaşımlar ile tasarım öğrencilerinin deneyim kazanması, problemleri her yönüyle ele almaları ve en iyi sonuca elde etme yollarına ulaşmaları sağlanmaktadır. Unutulmamalıdır ki belirli bir alandaki deneyim ve bilgi birikimi, uzmanlığın gelişimi için ön koşuldur (Casakin, Goldschmidt, 1999). Bu nedenle tasarım öğrencilerinin eğitim hayatları boyunca farklı yöntemler deneyimlemesi meslek hayatlarında onlarla birlikte gelecek olan önemli birikimler arasındadır.

Tasarım eğitiminde genel olarak bitkilendirme çalışmaları sörvey, analiz ve sentez aşamasından sonucu oluşturulan yapısal planın ardından tasarlanır. Oysaki bitkilendirme planlarının yapısal planlarla birlikte düşünülmesi ve birbirinden bağımsız planlamaması gereklidir. Bir tasarımda mekan sadece yapısal elemanlarla değil bitkisel elemanlarla da oluşturulabilir. Ayrıca sadece bitkisel elemanlarla mekan oluşturulabileceğide göz ardı edilmemelidir. Bu bağlamda, bu çalışmada tasarım sürecinde yapısal ve bitkisel öğelerin kurgulanmasının birarada düşünüldüğ̈̈, farklı bir yöntem ve tekniğe göre gerçekleştirildiği projeler incelenmiştir. Bu süreçte tasarım çalışmasında yapısal ve bitkisel doku aynı kurgu ile düşünülmüş fakat farklı katmanlar üzerinde çalışılarak birleştirilmiştir. Yapısal ve bitkisel dokuda katmanlaştırma yöntemi ile sonuç ürünlerine ulaşılmıştır. Proje sürecinde kullanılan yöntemin tasarım eğitimi ve tasarım öğrencileri üzerindeki katkıları incelenmiştir. 


\section{Materyal ve Metot}

Çalışmada kullanılan materyaller Karadeniz Teknik Üniversitesi Peyzaj Mimarlığı Bölümü 2017-2018 güz eğitim-öğretim döneminde Çevre Tasarım Proje-2 dersi kapsamında gerçekleştirilen çalışmalar arasından seçilmiştir. Çevre Tasarımı Proje-2 (ÇTP-2) tasarım öğrencilerinin almakla yükümlü olduğu çalışma alanının konumu belirli olan ilk projedir. Proje derslerinde sınıf mevcudu stüdyo yöneticisi sayısına göre gruplara ayrılmaktadır. 10-12 kişiden oluşan her öğrenci grubundan sorumlu bir stüdyo yöneticisi bulunmaktadır. Proje konusunun amacı ortak olmasına rağmen stüdyo yöneticisinin uzmanlık alanına göre şekillenen farklı vurgu noktaları ortaya çıkmaktadır. Stüdyo yöneticisinin yönlendirme tekniğiyle tasarım öğrencilerinin ürettiği projelerde çeşitlilik artmaktadır. Tasarım sürecinde öğrencilerin hafta hafta izlemesi gereken program genel bir format dâhilinde tasarım öğrencilerine dağıtılmaktadır (Şekil 1). Söz konusu format ortak olmasına rağmen farklılıklar izlenen yöntemlerle değişebilmektedir. Katmanlaştırma yöntemi de bu bağlamda tasarımlara farklı çözüm önerileri sağlayabilmektedir. Bu yöntemde dikkat edilmesi gereken en önemli unsur projenin "bitkisel ve yapısal" olmak üzere iki katmanda çözülmesinin gerekliliği olmuştur. Çalışmada, dönem sonunda teslim edilen 11 örnek arasından katmanlaştırma yöntemini en iyi ifade eden 5 örnek incelenmiştir.

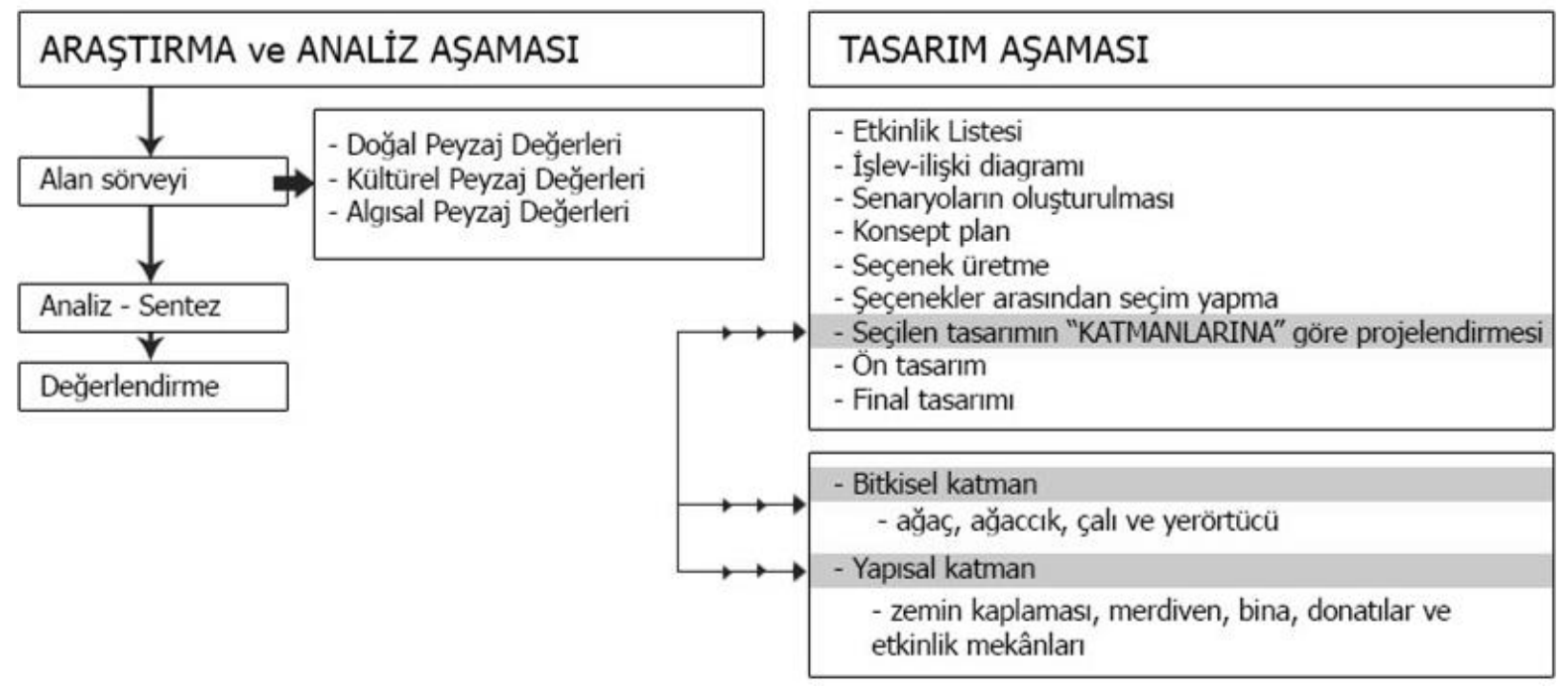

Şekil 1. Proje kapsamında tasarım öğrencileri ile izlenen program

Çalışma kapsamında incelenen bu yöntemde katmanlar bitkisel ve yapısal olmak üzere 2 ye ayrılmaktadır. Her birini oluşturan alt başlıklar bulunmaktadır. Projenin bitkisel ve yapısal katmanının çözümlenmesinin ardından tüm katmanlar birleşerek nihai proje oluşmaktadır. Tüm katmanlar birbirleri ile geri-beslemeli çalışmaktadır. Yöntem aşamaları Şekil 2'de anlatılmıştır.

Katmanlaştırma süreci yapısal katmanın çözümlenmesi, bitkisel katmanın çözümlenmesi ve tüm katmanların birleştirilmesini içeren katman olmak üzere üç bölümden oluşmaktadır.

Yapısal katman çözümlemesi bölümünde: yapısal elemanlarla mekan oluştururken bina, etkinlik alanları, bu alanların zemin malzemeleri, merdivenler, duvarlar, korkuluklar, bordürler ve donatılar kullanılmaktadır. Binanın girişi ve arka bahçeye çıkışları, evin odalarının konumları dış mekanların şekillenmesinde önemlidir. Etkinlik alanlarının kullanım biçimlerine göre büyüklükleri, zemin malzemeleri, eşyükselti eğrilerinin yoğunluğuna göre merdivenler ve duvarlar belirlenmektedir. Daha sonra etkinlikler için donatılar (sabit ve hareketli donatılar, barbekü, şezlong, kamerya, basket potası, çocuk oyun elemanları vs.) seçilmelidir.

Yapısal doku tasarlanırken bitkilerin estetik, işlevsel ve ekolojik fonksiyonlarının mekanlara olan etkileri gözardı edilmemelidir. Aksine bitkilerin bu fonksiyonları yapısal doku tasarımlarında pozitif yönde kullanılmalıdır. Bir sınır öğesi olan duvarların yerine bitkilerle oluşturulmuş çitler, gölge elemanlarının yerine tijli bitkilerin tercih edilmesi bunlara örnek verilebilir. Ayrıca bitkilerin renkleri, formları ve dokusal özellikleri ile mekanların olduğundan daha geniş veya daha yakın görünmesi sağlanabilir.

Bitkisel katman çözümlemesi bölümünde: bitkiler ile mekan oluştururken ağaç, ağaçcık, çalı ve yerörtücü grupları ayrı ayrı yada birlikte kullanılmaktadır. Bitki birlikteliklerinde bitkilerin renk, form, ölçü, doku ve çizgisel özelliklerine dikkat edilir. Bitkilerin kullanılacağı mekan özelliği ve mekanda bulunan yapısal öğelere uygun bitkisel tasarımlar gerçekleştirilmelidir. Bunların yanı sıra bitki seçimleri bitkilerin ekolojik istekleri ve 
mekanda kullanılacakları işlevsel özelliklere göre yapılmalıdır. Bu nedenle bitkisel tasarımlar mekanlarda bulunan yapısal dokularla birlikte düşünülmeli ve katmanlaştırılarak planlanmalıdır.

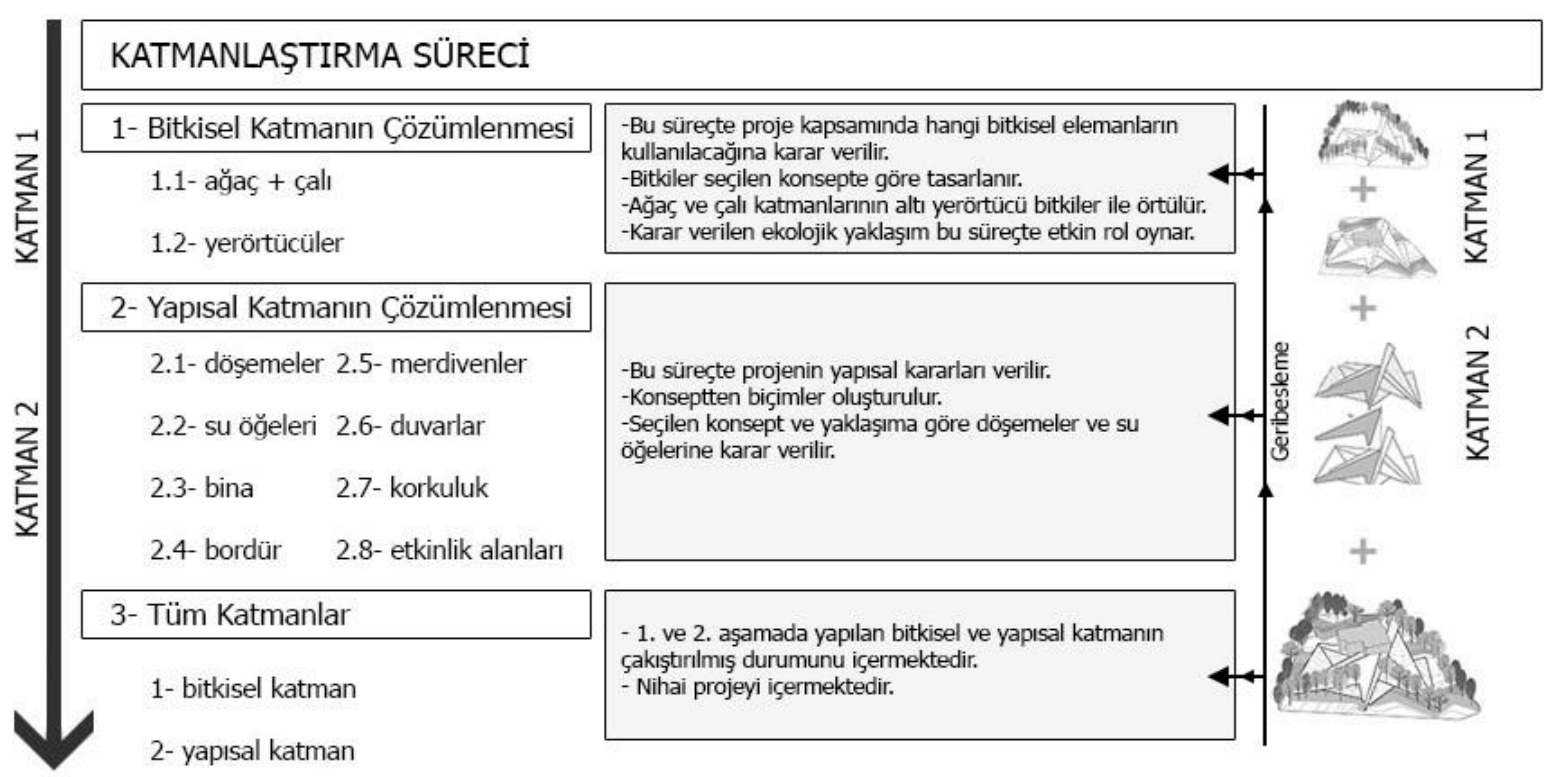

Şekil 2. Proje kapsamında incelenen projeler

Tüm katmanların birleştirilmesi: tasarım sürecinde konsept ve kullanıcı gereksinimlerine göre üretilen seçeneklerde yapısal ve bitkisel dokuya ait genel karakter dokusu belirlenmiş olmaktadır. Üretilen seçenekler arasından seçilen tasarım katmanlandırılarak her katmanın hem tek başına hem de çevresindeki diğer öğelerle olan durumu detaylandırılır. Bu şekilde oluşturulan katmanların birleştirilmesiyle nihai proje elde edilmiş olur. Katmanlaştırma yönteminin tasarım sürecine ve öğrencilerin tasarım eğitimine: aşağıdaki katkıları sağlayacağı düşünülmektedir:

- Bitkisel ve yapısal dokunun birbirinden ayrı düşünülmemesinin gerekliliği,

- Her iki katmana dair tüm detayların daha iyi algılanabileceği,

- Proje süresince tasarım ilke ve öğelerinin hem bitkisel hem de yapısal katman için ayrı ayrı düşünülmesinin gerekliliği,

- Yapısal ve bitkisel dokunun daha kolay algılanıp çözülebileceği,

- Stüdyo yöneticisi ve tasarım öğrencilerinin bu süreci deneyimlemesinin getireceği katkılar,

- Çizdikleri her çizginin yapısal ve bitkisel doku için ayrı şeyleri ifade ettiğinin deneyimleyerek farkına varmalar1,

- Konsept ve senaryonun hem bitkisel katman hem de yapısal katman için düşünülmesi,

- Dönem sonunda hepsi çakıştırılarak final projesinin oluşturulmasının getireceği kolaylık,

- İleride meslek hayatında her iki katmanında birlikte düşünülmesinin getirdiği sorumluluk duygusu,

- Tasarım eğitimine "katmanlaştırma" yöntemi ile farklı bir teknik ile bakış açısı getirebilme,

- Önerilen yöntemin mimarlık, peyzaj mimarlığı, şehir bölge planlama gibi birçok meslek disiplini için bir rehber niteliği taşıyacak olması,

- Aldıkları bu projenin ilk projeleri oluşu ve bu bilgi birikimi ile ilerideki projelerini de çözebilecekleri,

- Bitkisel ve yapısal dokunun ayrı düşünülüp proje sonucunda bir bütüne hizmet etmesinin gerekliliğini daha iyi kavrayabilecekleri.

\section{Bulgular ve Tartışma}

Yapılan bu çalışma kapsamında Çevre Tasarım Proje-2 dersinde tasarım öğrencilerine ait projelerin tasarım konsepti, kullanıcı grubu, etkinlikleri ile ilişkili mekân kurgusu ve mekanların yeşil alanlarla olan ilişkisi elde edilen sonuç ürünler üzerinde incelenmiştir. 
Araştırılan bu beş örnekte ilk olarak projenin ana konsepti belirlenmiştir. Ana konsepte uygun hem yapısal hemde bitkisel katman geliştirilmiştir. Yapısal katmanda kullanıcı ve konset tasarıma karakter kazandıran en önemli öğelerdir. Kullanıcı istekleri ve konsete uygun karakter belirleme arazi olanakları göz önünde bulundurularak yapısal katman oluşturulur. Yapısal karaktere şekil veren konsept, bitki tür seçiminde belirleyici öğe olarak değerlendirilmiştir. Konsept bitki türlerinin sadece estetik özelliklerine değil ekolojik ve fonksiyonel özelliklerini de ön plana çıkarmaktadır. Bitki birliktelikleri (ağaç, ağaçcık, çalı, yerörtücü, çim), kitle-boşluk durumu, yapısal öğeler ve tüm çalışma alanı özellikleri düşünülerek bitkisel katman nihayi sonuca ulaştırılır. İncelenen birinci projenin konsepti sürdürülebilirlik olarak belirlenmiştir. Ekosistemin sürdürülebilirliğinin sağlanmasında en önemli varlıklar arılar olduğu için tasarıma yön vermek amacı ile polen bahçeleri üzerinde yoğunlaşılmıştır. Bu yaklaşıma uygun olarak bal özelliği olan ağaç ve çalı grupları belirlenmiştir. Yer örtücüler için bitkilerin renk ve hayvanları cezbedeceği özellikleri dikkate alınmıştır. Kullanıcı grup olarak çevre dostu, arıcılıkla ilgilenen aile bireyleri düşünülmüştür. Bu nedenlerle tasarım deseni için bal peteği kullanılmıştır. Petek dokusu soyutlanarak tasarımın yapısal katmanında mekânlar kurgulanmış ve etkinlikler oluşturulmuştur. Yapısal katman bitkisel katmanı destekleyecek şekilde tasarlanmıştır. Yapısal katman birlik-egemenlik-denge, vurgu-odak ve ritim-tekrar ilkelerine ağırlık verilerek oluşturulmuştur. Bitkisel katman ise daha çok bitkilerin meyve, çiçek ve koku özeliklerine dikkat edilerek uyum, birlik ve süreklilik ilkelerine ağırlık verilerek oluşturulmuştur. Genel olarak tasarım yaklaşımında tasarımın özgün, tematik ve sürdürülebilir olması tercih edilmiştir (Tablo 1).

İkinci projede konsept olarak huzur seçilmiştir. Sakin, huzur verici bir bahçe oluşturmak için suyun dinlendirici özelliğinden yararlanılmıştır. Bu nedenle suyun içyapısı ve dokusuna dair örnekler incelenmiş çeşitli eskiz ve soyutlama çalışmaları yapılmıştır. Damlaların su içinde kırılma biçimleri soyutlanıp tasarım deseni oluşturulmuştur. Kullanıcı grup olarak doğa dostu, yoga ile ilgilenen sporcu aile bireyleri düşünülmüştür. Yapısal katmandan çok bitkisel katmanın ve suyun ön planda olduğu tasarımda insanların yeşile temas etmesi ve huzuru hissetmesine önem verilmiştir. Bitkisel katman için su kenarında yetişebilen ve sudaki yansımaları etkili görüntüler sergileyen bitki türleri tercih edilmiştir. Aynı zamanda seçilen türlerin sonbahar renklenmeleri ile suda yansıyıp güzel bir perspektif oluşturabilmelerine dikkat edilmiştir. Her iki katmanda da egemenlikdenge, vurgu-odak ilkeleri ağırlıklı olarak kullanılmıştır. Tasarım yaklaşımlarında ise bitkisel katmanda, tasarımın özgün, tematik, ekolojik kaygılı olması tercih edilirken, yapısal katmanda, tasarımın özgün ve tematik olması tercih edilmiştir (Tablo 2).

Üçüncü projede doğanın düzeni konsept olarak seçilmiş, düzenin kelime anlamından ötürü organik formlardan çok yapay formlar tercih edilmiştir. Tasarım deseni için kaya formlarından yola çıkılıp soyutlama çalışmaları yapılmıştır. Kaya örneklerinden elde edilen doku ile mekânlar kurgulanmıştır. Kullanıcı grup olarak kayaları ve bitkileri şekillendiren heykeltraşlar seçilmiştir. Yapısal ve bitkisel katmanlarda düzeni yansıtmak için yapay geometrik formlardan yararlanılmış, uyum, ritim-tekrar ilkelerine ağırlık verilmiştir. Bitkisel katmanda dağınık formlu bitkilerin yerine oval ve sutun formlu bitkiler kullanılmıştır. Ayrıca budanarak şekil verilebilecek bitki türlerine önem verilmiştir. Tasarım yaklaşımında yapısal katmanda tasarımın özgün olması ön planda iken bitkisel katmanda tasarımın özgünlüğü, tematik ve sürdürülebilir olmasına önem verilmiştir (Tablo 3).

Dördüncü projenin konsepti sosyalleşme olarak belirlenmiştir. Sosyalleşmenin farklı özellikteki bireyleri biraraya getirmesinden yola çıkarak tasarım deseninde çizgisel yapıların farklılıkları temsil ettiği merkezsel oluşumları ifade eden örnekler araştırılmıştır. Kullanıcı grup olarak medya sektöründe çalışan yapımcı aile bireyleri seçilmiştir. Yapısal katmanda egemenlik-denge, vurgu-odak, ritim-tekrar, koram-hiyerarşi, birlikörüntü ilkeleri ağırlıklı kullanılmıştır. Bitkisel katmanda konsepti destekleyecek şekilde merkezden dağılmaya dikkat edilmiştir, bitkiler çizgisel olarak gruplandırılmıştır. Bu katmanda uyum- zıtlık, vurgu-odak, ritim-tekrar, koram-hiyerarşi, birlik-örüntü ilkeleri ağırlıklı kullanılmıştır. Bitki tür seçiminde ise çizgiselliği ön plana çıkarmak amacı ile kaligrafik özelliği olan türler tercih edilmiştir. Tasarım yaklaşımında hem yapısal hem de bitkisel katmanda tasarımın özgün, tematik ve sürdürülebilir olamsına önem verilmiştir (Tablo 4).

Beşinci projenin konsepti için günümüzde su sorununu düşünerek kurakçıl peyzaj çalışmaları üzerine yoğunlaşılmış ve susuz yaşam konsept olarak belirlenmiştir. Tasarım desenini oluşturmak için kurak toprakların görünümleri araştırılmış elde edilen örneklere uygun formlar belirlenerek soyutlama çalışmaları gerçekleştirilmiştir. Kullanıcı grup olarak su isteği az olan bitkiler üzerinde çalışan botanikçi bireyler düşünülmüştür. Tasarım sürecinde bitkisel katmanda bitki tür seçiminde konsepte uygun olacak şekilde su isteği az, ekolojik açıdan kanaatkar, doğal ve az bakım isteyen türler belirlenmiştir. Yapısal katmanda birlik-örüntü, bitkisel katmanda ise uyum- zıtlık, egemenlik-denge, vurgu-odak, ritim-tekrar, birlik-örüntü ilkeleri ağırlıklı olarak kullanılmıştır. Tasarım yaklaşımında yapısal katmanda tematik ve sürdürülebilirlik, bitkisel katmanda ise özgün, tematik, doğal ve ekolojik kaygı ön planda tutulmuştur (Tablo 5).

Projelerde bitkisel katmanlarda en çok egemenlik-denge, vurgu-odak, ritim-tekrar, birlik-örüntü, en az en koram-hiyerarşi, birlik-örüntü tasarım ilkelerinin kullanıldığı belirlenmiştir. Yapısal katmanda ise egemenlikdenge, vurgu-odak, ritim-tekrar ilkeleri en çok kullanılan ilkeler arasında olmuştur. Neredeyse tüm projelerde öğrenciler tasarım yaklaşımlarının özgün ve sürdürülebilir olmalarına dikkat etmişlerdir. 
Tablo 1. Çalışma kapsamında incelenen 1 nolu proje

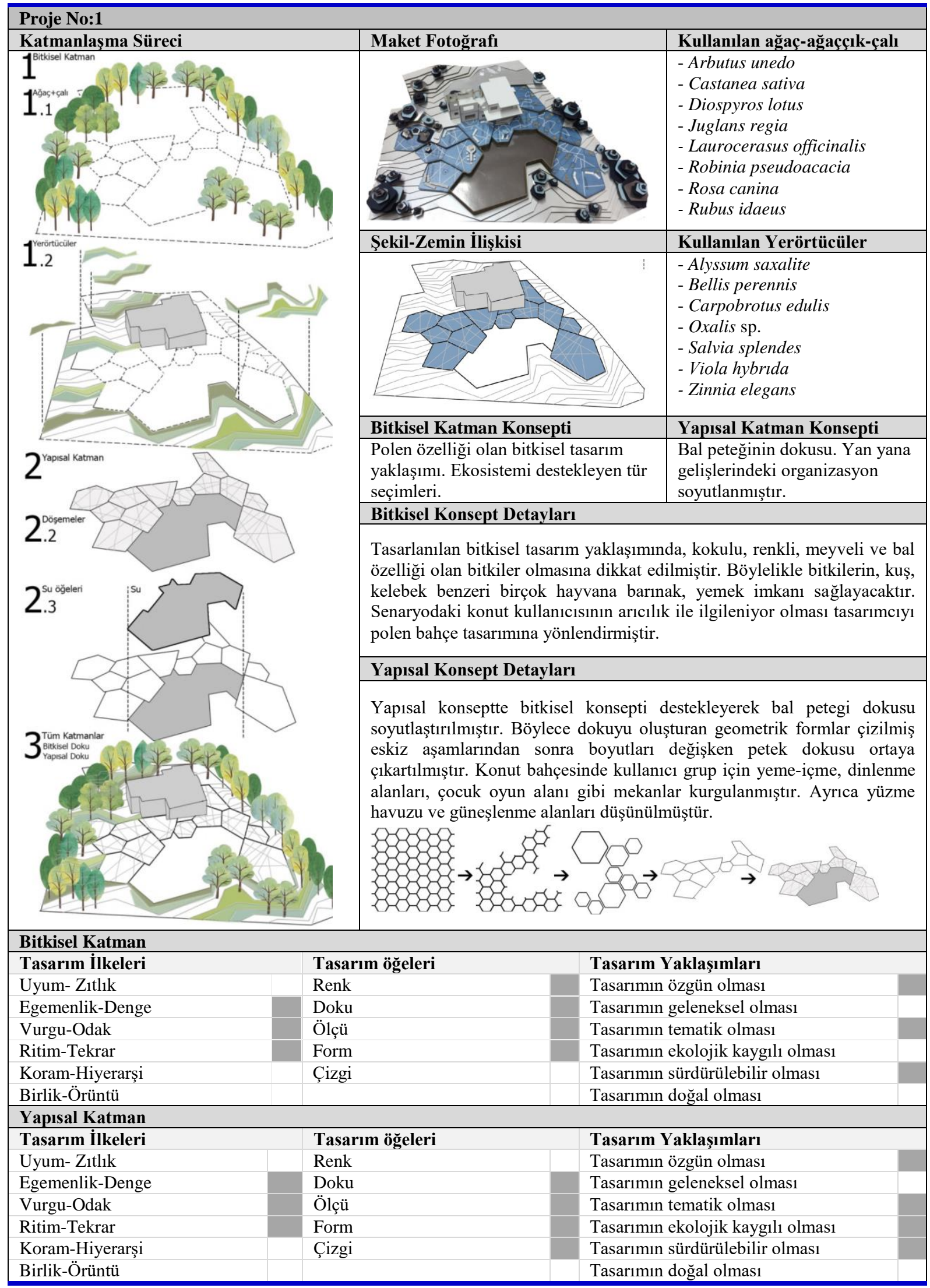


Tablo 2. Çalışma kapsamında incelenen 2 nolu proje

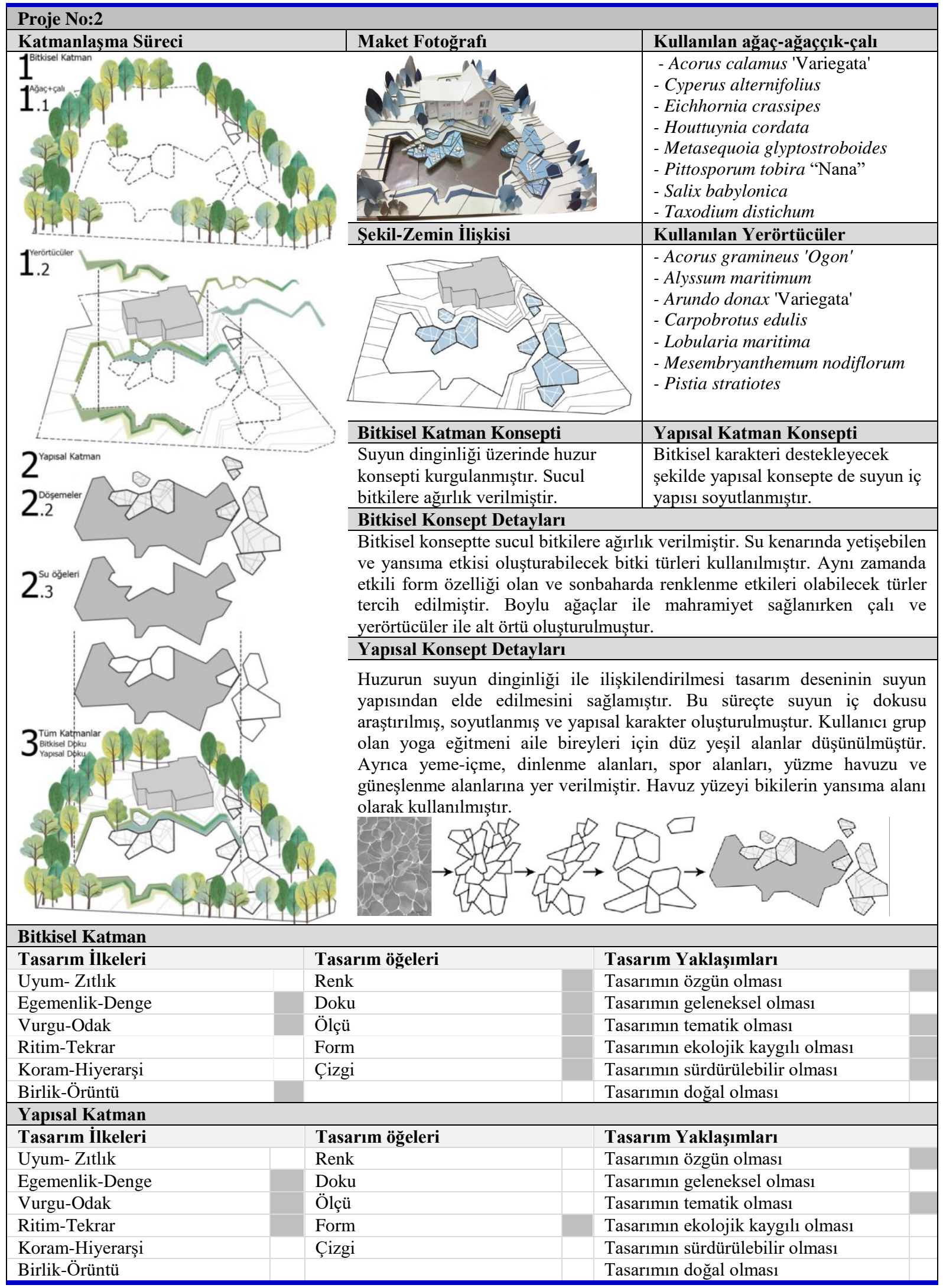


Tablo 3. Çalışma kapsamında incelenen 3 nolu proje

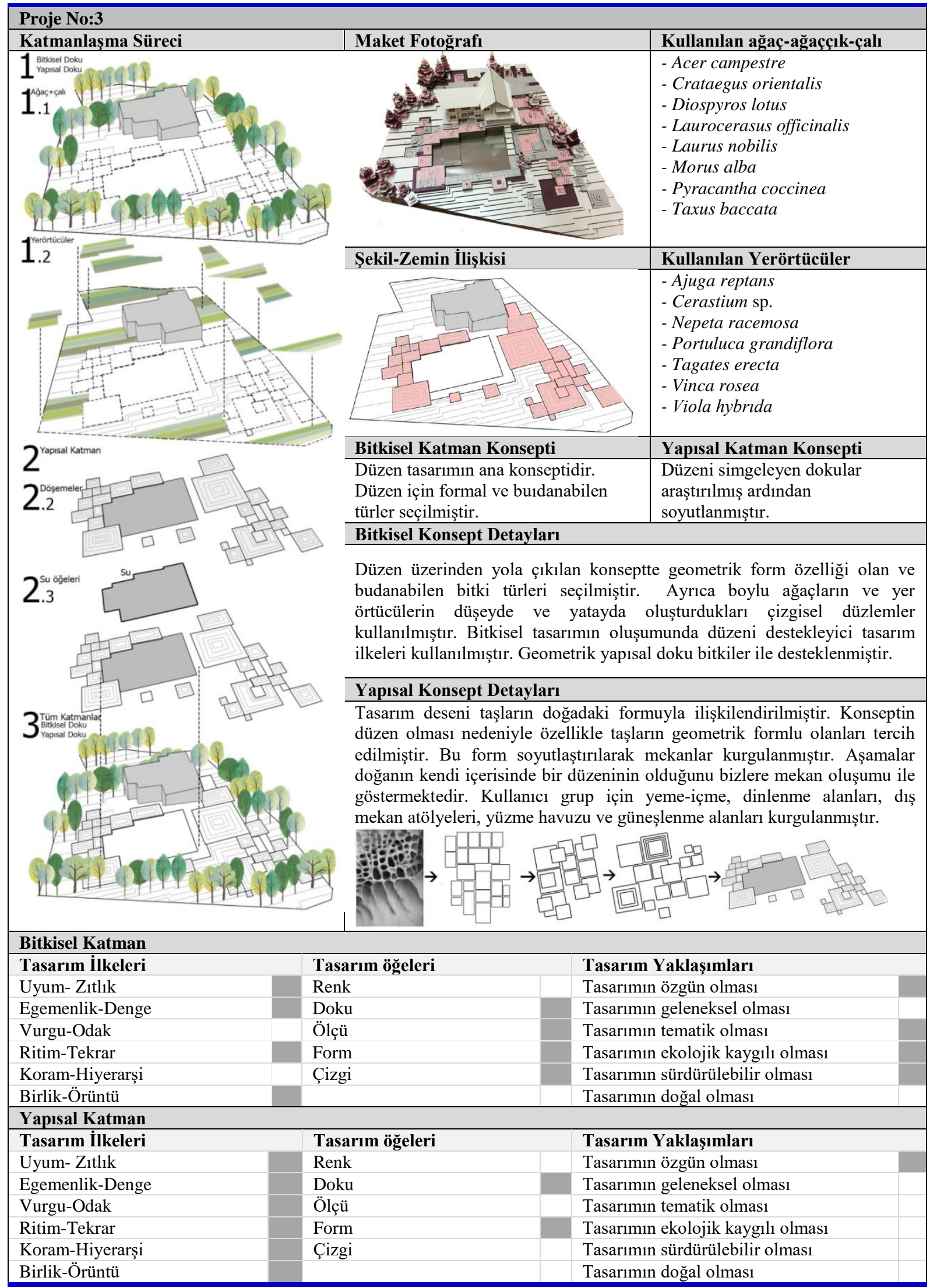


Tablo 4. Çalışma kapsamında incelenen 4 nolu proje

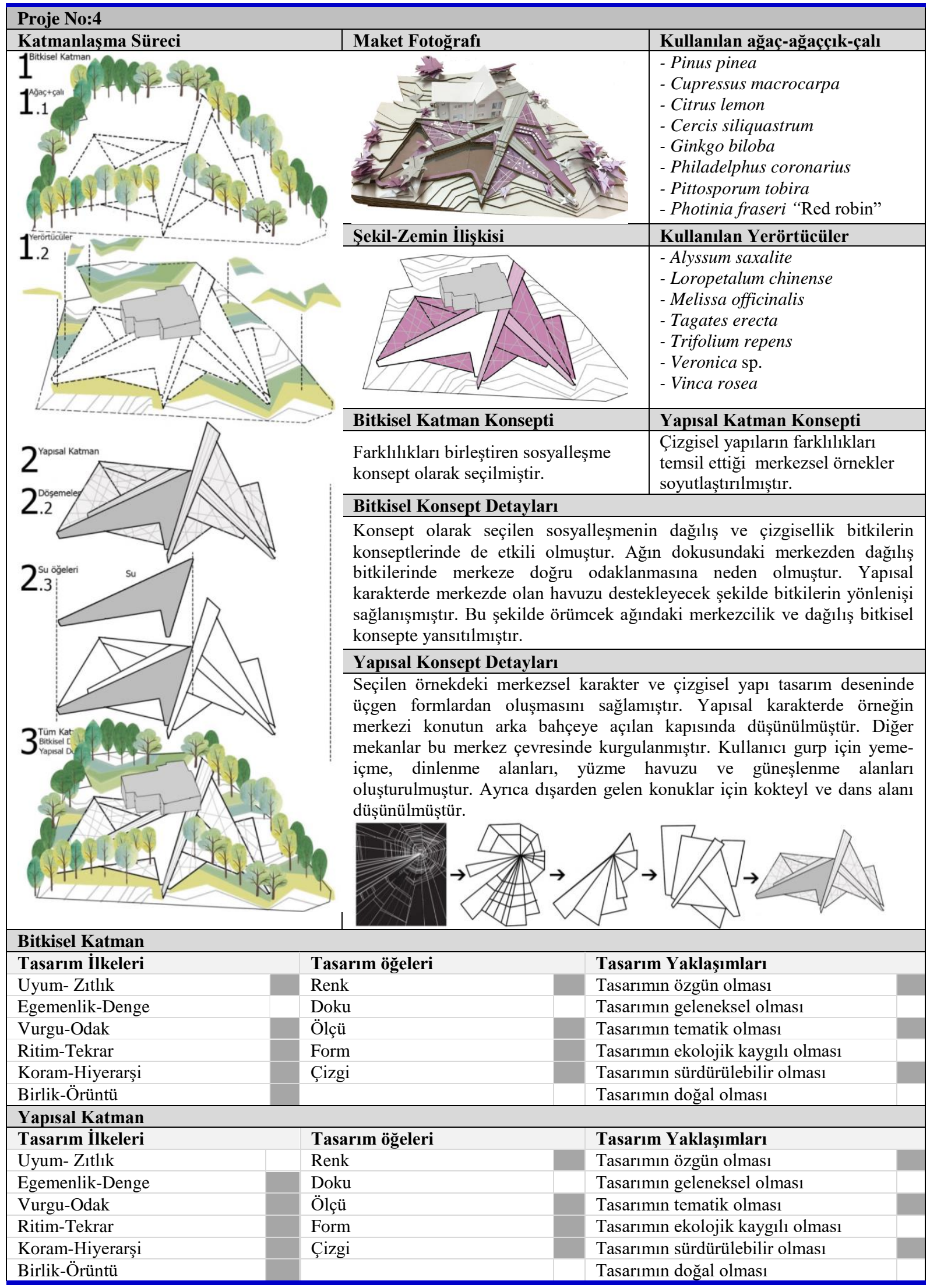


Tablo 5. Çalışma kapsamında incelenen 5 nolu proje

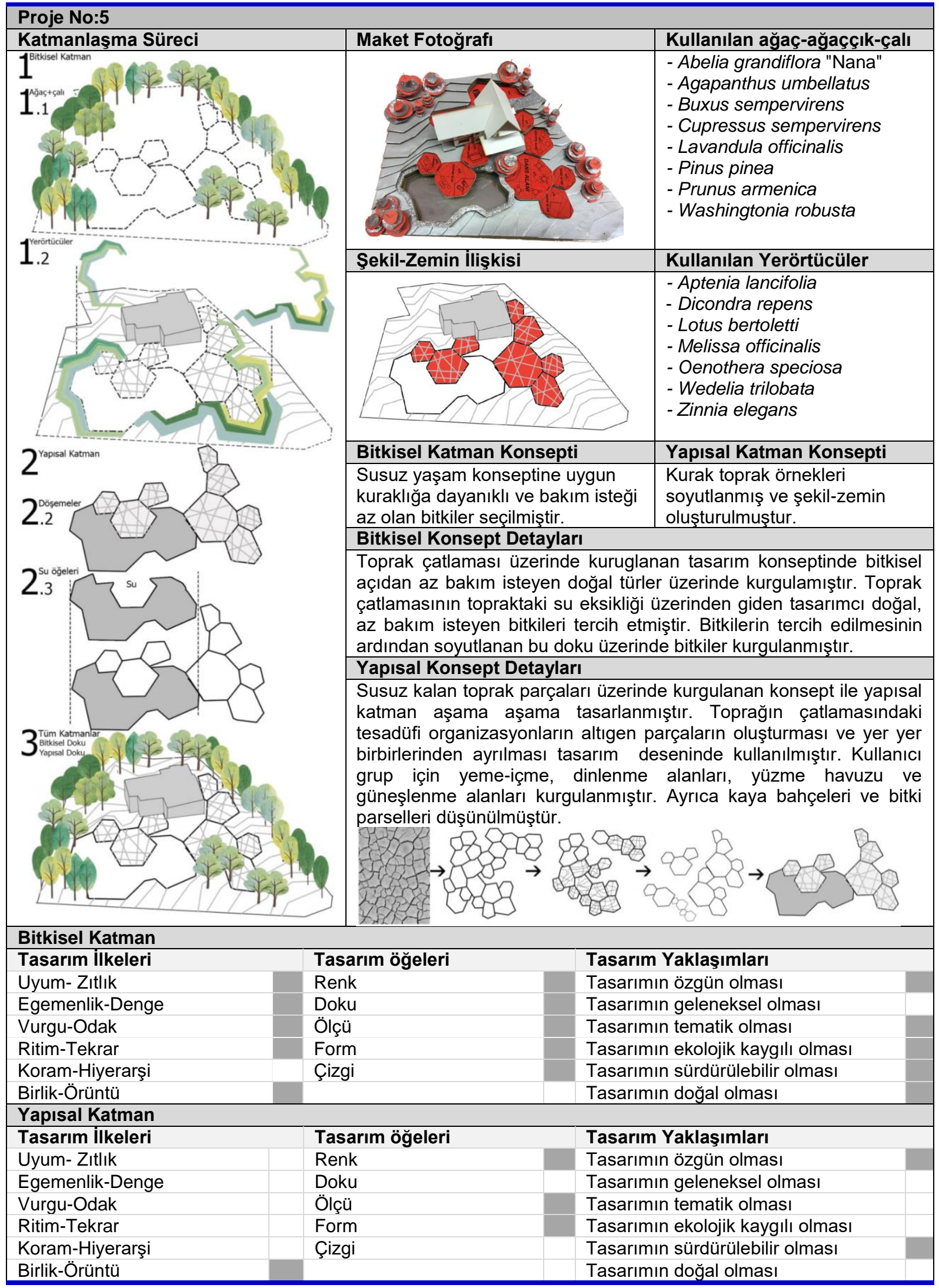




\section{Sonuç ve Öneriler}

Yapılan bu çalışmada, tasarım öğrencilerinin tasarım sürci içerisinde projelerini; bitkisel ve yapısal katman olmak üzere 2 ayrı şekilde çözümlemesi üzerinde durulmuştur. Sonuçta, tasarım öğrencilerinin esinlendikleri kaynakları yapısal ve bitkisel katmanlara nasıl yansıttıkları irdelenmiş ve bu katmanları tanımlamaya ilişkin eğilimleri araştırılmıştır. Tasarım süreci esinlendikleri örnekleri bu katmanlarda çözemlemeleri ile oluşturulmuştur.

Ağırlıklı olarak tasarım öğrencileri; çalışma alanına ilişkin ekolojik veriler, konut-kullanıcı ilişkisi ve alanın fiziksel/morfolojik özellikleri üzerinde durmuşlardır. Sürecin başlangıcında çalışma alanını tanımlamış ve araştırmışlardır. Sonrasında bu verilere uygun şekilde senaryo ve konseptlerini geliştirmişlerdir. Tam da bu süreçte, senaryolarında sadece yapısal dokuyu ya da sadece bitkisel dokuyu düşünmek yerine her iki dokuyu düşünerek kararlar almaları istenmiştir. Yapısal ve bitkilsel katmanların bir bütünün parçaları olması gerekliliği, tasarımlarda yapısal katmandan sonra bitkisel katmanın oluşturulması kanısının tasarımda eksikliklere neden olabileceği noktasına dikkat edilmiştir. Bu süreçte bitkilerin önemi ve tasarımlarda bitki kullanımı ile neler yapılabileceği örneklerle tasarım öğrencilerine anlatılmıştır. Peyzaj mimarlığının canlı materyali olan bitkilerin renkleri, formları ve dokusal özellikleri ile mekanlara dinamizm kazandırması, renklenme özellikleri ile kullanıcıların zamansal değişimleri algılamasında farkındalık oluyşturması gibi pozitif etkileri vurgulanmıştır. Bütün bunların yanısıra bitkilerin insanlar üzerindeki olumlu etkileri ve bu etkilerin bilimsel araştırmalarla tespit edildiği çalışmalar gösterilmiştir. Tasarımcının bitkileri belirlediği konseptele ilişkilendirmesiyle oluşan etkili peyzajları ve bu peyzajların kullanıcılara mekan duygusu kazandırdığı örnekler irdelenmiştir. Ayrıca yeşil alanların günden güne azaldığı günümüz dünyasında kentsel alanlarda bitkilerin kullanımları ve bitkilerin kent ekosistemindeki olumlu etkileri çeşitli örneklerle açıklanmıştır. Peyzaj mimarlığı meslek disiplininin en önemli tasarım elemanlarında olan bitkilerin proje sürecinin en son basamağında yer alması önemli sorunlardan biridir. Tasarım öğrencilerine, bu sorunun giderilmesinde proje sürecinde katmanlaştırma yöntemin önemli bir katkısı olacağı iletilmiştir. Yöntemi deneyimlemeleri ile daha başarılı, daha doğru projeler elde edileceği anlatılmıştır.

Tablo 6. Projelerin dönem sonunda değerlendirme kriterleri

\begin{tabular}{|c|c|c|c|c|c|}
\hline $\begin{array}{l}\text { Değişkenler } \\
\text { Bitkisel Katman }\end{array}$ & Pro .1 & Pro. 2 & Pro. 3 & Pro. 4 & Pro. 5 \\
\hline Seçilen türlerin arazi ve iklim verilerine uygunluğu, & $\bullet$ & $\bullet$ & $\bullet$ & $\bullet$ & $\bullet$ \\
\hline Tasarım yaklaşımına göre bitki tür seçimi, & $\bullet$ & $\bullet$ & $\bullet$ & $\bullet$ & $\bullet$ \\
\hline Yapısal katmana uygunluğu, & $\bullet$ & $\bullet$ & $\bullet$ & $\bullet$ & $\bullet$ \\
\hline Konsept dâhilinde tasarlanması, & $\bullet$ & $\bullet$ & $\bullet$ & $\bullet$ & $\bullet$ \\
\hline Tasarım ilke/ elemanları ile tasarlanan organizasyon, & $\bullet$ & • & $\bullet$ & $\bullet$ & • \\
\hline Yapisal Katman & & & & & \\
\hline Esinlenilen örnek ile şekil-zemin organizasyonu, & $\bullet$ & $\bullet$ & • & $\bullet$ & $\bullet$ \\
\hline Tasarım yaklaşımına göre malzeme seçimi, & $\bullet$ & $\bullet$ & $\bullet$ & $\bullet$ & $\bullet$ \\
\hline Bitkisel katmana uygunluğu, & $\bullet$ & $\bullet$ & $\bullet$ & $\bullet$ & $\bullet$ \\
\hline Konsept dâhilinde tasarlanması, & $\bullet$ & $\bullet$ & $\bullet$ & $\bullet$ & • \\
\hline Tasarım ilke/ elemanları ile tasarlanan organizasyon, & $\bullet$ & $\bullet$ & $\bullet$ & $\bullet$ & $\bullet$ \\
\hline
\end{tabular}

Dönem sonundaki süreçte stüdyo yöneticisinin beklentileri neticesinde bitkisel ve yapısal dokunun başarılı bir şekilde elde edilip edilemediği Tablo 6'da irdelenmiştir. Sonuçta tasarım öğrencilerinin kendi yaratıcılıkları ve dönem boyundaki çabaları neticesinde projeleri oluşmuştur. Dönem başında verilen tasarım problemi başarı ile ortaya konulmuştur. Tasarım öğrencileri bu süreçteki metodu deneyimlerken, projelerini daha kolay bir şekilde çözmüştür. En önemlisi ise, yapısal ve bitkisel doku ayrıntıları ile birlikte düşünülüp tasarım kararları alınmıştır. Yapısal katman ve bitkisel katman ayrı ayrı düşünülmemiş süreç sonunda çakıştırılmıştır. Senaryo her iki katman için kurgulanmıştır. Bu yöntemle başarılı sonuçlar elde edilmiştir. Aynı zamanda tasarım öğrencileri projelerini farklı bir dil ile ifade etmiş ve deneyimlemiştir. Uygulanan bu sürecin peyzaj mimarlığı, şehir bölge planlama, mimarlık ve iç mimarlık gibi meslek disiplinlerinde kullanılabileceği düşünülmektedir. Bu nedenle yapılan bu çalışmanın tasarım eğitiminde sürdürülebilir bir değeri bulunmaktadır. İleride yapılacak olan çalışmalar ile, proje konuları farklı olsa da bu yöntem değerlendirilebilir ve aralarındaki ilişli araştırılabilir. Sonuç olarak bu çalışma kapsamında işlenilen bu yöntem sayesinde,tasarım öğrencileri projelerini yapısal olduğu kadar bitkisel açıdanda daha başarılı bir şekilde ortaya koymuştur. En önemlisi ise, bitkisel ve yapısal katman bir bütünün parçası olacak şekilde düşünülmüş, senaryo ve konsept her iki katman ilişkilendirilerek elde edilmiştir. 


\section{Teşekkür}

Yapılan bu çalışma Karadeniz Teknik Üniversitesi, Peyzaj Mimarlığı Bölümü, 2017-2018 Güz Dönemi Çevre Tasarım Proje-2 dersi kapsamındaki öğrenci çalışmaları üzerine kurgulanmıştır. Yazarlar, projelerinden yararlandıkları öğrenciler; Ebrar ÇOBAN, Sedanur TETİK, Neziha Nur KABLANDER, Haticenur DEMİRSOY, Cahide ÖZÇAĞDAVUL'a katkılarından ve dönem içerisindeki performanslarından dolayı teşekkürlerini bildirirler.

\section{Kaynaklar}

1. Acar H., Bekar M. (2017). Peyzaj mimarlı̆̆ı eğitiminde bir stüdyo çalışması: kıyı alanı peyzaj tasarım projesi. Megaron, 12, 329-342.

2. Bonnardel, N. (2000). Towards understanding and supporting creativity in design: analogies in a constrained cognitive environment, Knowledge-Based Systems, 13, 505-513.

3. Casakin, H., Goldschmidt, G. (1999). Expertise and the use of visual analogy: Implications for design education. Design Studies, 20(2), 153-175.

4. Casakin H. P. (2007). Factors of metaphors in design problem-solving: implications for design creativity. International Journal of Design, 1, 21-33.

5. Casakin, H. P. (2011). Associative Thinking as a Design Strategy and its Relation to Creativity, International Conference on Engineering Design, 15-18 August 2011, Denmark.

6. Casakin, H., Van Timmeren, A. (2014). Analogies as creative inspiration sources in the design studio: the teamwork. Athens Journal of Architecture, 1(1);51-64.

7. Çağlayan Kaptanoğlu, A. Y. (2008). Peyzajın görsel analizinde grafik düşünme süreci ve soyutlama. Journal of the Faculty of Forestry Istanbul University, 58(1), 25-38.

8. Demirbaş O. O., Demirkan, H. (2003). Focus on architectural design process through learning styles. Design Studies, 24, 437-456.

9. Düzenli, T., Alpak, E. M. (2016). Peyzaj Mimarlığı Eğitiminde Doğaya Öykünme Yaklaşımının Yaratıcılık Üzerindeki Etkisi. Mimarlık ve Yaşam Dergisi, 1(1), 13-21.

10. Düzgün Bekdaş, H., Yıldız, S. (2018). Tasarım ve Sanat Arakesitinde Kavramsal Düşünme: Enformel Eğitim Çalışmaları (2009-2015). Megaron, 13(2).

11. Francis, M. (2001). A case study method for landscape architecture. Landscape Journal, 20(1), 15-29.

12. Fischbach, G. D. (1992). Mind and brain. Scientific American, 267(3), 48-59.

13. Goldschmidt, G. (1997). Capturing indeterminism: representation in the design problem space, Design Studies, 18(4), 441-455.

14. Goldschmidt, G., Sever, A.L. (2009). From text to design solution: inspiring design ideas with texts, International Conference on Engineering Design, 15-26, 24-27 August 2009, USA.

15. Kvan, T., Yunyan, J. (2005). Students' learning styles and their correlation with performance in architectural design studio, Design Studies, 26, 19-34.

16. Mumcu S., Düzenli T. (2018). Peyzaj mimarlığı tasarım stüdyosunda kavramsal yaklaşımlar ve esin kaynakları, Megaron, 13, 665-678.

17. Önal, G.K. (2011). Yaratıcılık ve kültürel bağlamda mimari tasarım süreci. Uludağ Üniversitesi Mühendislik-Mimarlık Fakültesi Dergisi, 16(1), 155-162. 
18. Paker Kahvecioğlu, N. (2001). Mimari Tasarım Eğitiminde Bilgi ve Yaratıcılık Etkileşimi. Doktora Tezi, İstanbul Teknik Üniversitesi Fen Bilimleri Enstitüsü, İstanbul.

19. Roberts, A. (2005). Cognitive styles and student progression in architectural design education. Design Studies, 27(2), 167-181.

20. Tezci, E., Gürol, A. (2003). Olusturmacı öğretim tasarımı ve yaratıcılık. The Turkish Online Journal of Educational Technology, 2(1), 50-55. 